\title{
Pten Deletion in Adult Neural Stem/Progenitor Cells Enhances Constitutive Neurogenesis
}

\author{
Caroline Gregorian, ${ }^{1}$ Jonathan Nakashima, ${ }^{1}$ Janel Le Belle, ${ }^{1}$ John Ohab, ${ }^{2}$ Rachel Kim, ${ }^{1}$ Annie Liu, ${ }^{1}$ Kate Barzan Smith, ${ }^{1}$ \\ Matthias Groszer, ${ }^{1,3}$ A. Denise Garcia, ${ }^{4}$ Michael V. Sofroniew, ${ }^{4}$ S. Thomas Carmichael, ${ }^{2}$ Harley I. Kornblum, ${ }^{1,5}$ Xin Liu, ${ }^{1,3}$ \\ and Hong $\mathrm{Wu}^{1}$ \\ Departments of ${ }^{1}$ Molecular and Medical Pharmacology, ${ }^{2}$ Neurology, ${ }^{3}$ Pathology and Laboratory Medicine, and ${ }^{4}$ Neurobiology, ${ }^{5}$ The Semel Institute, David \\ Geffen School of Medicine, University of California, Los Angeles, Los Angeles, California 90095
}

Here we show that conditional deletion of Pten in a subpopulation of adult neural stem cells in the subependymal zone (SEZ) leads to persistently enhanced neural stem cell self-renewal without sign of exhaustion. These Pten null SEZ-born neural stem cells and progenies can follow the endogenous migration, differentiation, and integration pathways and contribute to constitutive neurogenesis in the olfactory bulb. As a result, Pten deleted animals have increased olfactory bulb mass and enhanced olfactory function. Pten null cells in the olfactory bulb can establish normal connections with peripheral olfactory epithelium and help olfactory bulb recovery from acute damage. Following a focal stroke, Pten null progenitors give rise to greater numbers of neuroblasts that migrate to peri-infarct cortex. However, in contrast to the olfactory bulb, no significant long-term survival and integration can be observed, indicating that additional factors are necessary for long-term survival of newly born neurons after stroke. These data suggest that manipulating PTEN-controlled signaling pathways may be a useful step in facilitating endogenous neural stem/progenitor expansion for the treatment of disorders or lesions in regions associated with constitutive neurogenesis.

Key words: SEZ; PTEN; neurogenesis; olfactory; neural repair; poststroke

\section{Introduction}

The adult CNS contains self-renewing stem cells capable of generating new neurons, astrocytes, and oligodendrocytes, a process evolutionarily conserved in birds, rodents, primates, and humans (Doetsch, 2003). The subependymal zone (SEZ) is one of at least two areas of adult neurogenesis where glial fibrillary acidic protein (GFAP) expressing cells act as slow-dividing neural stem cells (NSCs) capable of generating neuroblast precursors (Doetsch, 2003; Garcia et al., 2004; Lledo et al., 2006). The neuroblasts migrate into the rostral migratory stream (RMS) and then into the olfactory bulb $(\mathrm{OB})$ where they differentiate into granule and periglomerular neurons (Luskin, 1993; Lois et al., 1996; Petreanu and Alvarez-Buylla, 2002; Hack et al., 2005; Curtis et al., 2007). Since the majority of granule neurons in the $\mathrm{OB}$ are generated postnatally (Petreanu and Alvarez-Buylla, 2002), it is believed

Received July 3, 2008; revised Nov. 8, 2008; accepted Dec. 17, 2008.

This work was supported by Miriam and Sheldon Adelson Program in Neural Repair and Rehabilitation (to H.W., S.T.C., M.V.S., H.I.K.), National Institutes of Health Grants NS047386 (to M.V.S.) and MH65756 (to H.I.K., H.W.), Brain Tumor Society (to X.L., H.W.), and Henry Singleton Brain Cancer Research Program and James S. McDonnell Foundation Award (to H.W.). C.G. and K.B.S. are predoctoral trainees supported by United States Department of Health and Human Services Ruth L. Kirschstein Institutional National Research Service Award T32 CA09056. We thank Dr. Guoping Fan and members of our laboratories for helpful comments on this manuscript.

The authors declare no competing financial interests.

Correspondence should be addressed to Dr. Hong Wu, Department of Molecular and Medical Pharmacology, CHS 23-214, University of California, Los Angeles School of Medicine, 650 CE Young Drive South, Los Angeles, CA 900951735. E-mail: hwu@mednet.ucla.edu.

M. Groszer's present address: Wellcome Trust Centre for Human Genetics, University of Oxford, Roosevelt Drive, Oxford OX3 7BN, UK

DOI:10.1523/JNEUROSCI.3095-08.2009

Copyright $\odot 2009$ Society for Neuroscience $\quad$ 0270-6474/09/291874-13\$15.00/0 that continued neoneurogenesis from the SEZ is critical for maintaining the homeostasis of the $\mathrm{OB}$ and therefore the olfactory functions (Goldman, 1998).

NSC-mediated neoneurogenesis is also believed to participate in the process of neural repair. Recent findings suggest endogenously generated new neurons participate in the formation of circuitry and at least some functional recovery following neurological damage such as stroke (Yamashita et al., 2006). Therefore, understanding the molecular mechanisms and pathways capable of activating and expanding neural stem/precursor cell (NS/PC) populations, stimulating their migration toward damaged or diseased areas, enhancing their survival, and promoting their maturation and integration into the existing neural circuitries may ultimately lead to repair and improve damaged neuronal functions (Peterson, 2002; Emsley et al., 2005).

Phosphatase and tensin homolog deleted on chromosome 10 (PTEN) encodes a phosphatase and is a potent antagonist of phosphatidylinositol-3-kinase (PI3K) (Liaw et al., 1997; Nelen et al., 1997; Li et al., 1998) and its regulated pathways (Lee et al., 1999; Maehama et al., 2001; Vivanco and Sawyers, 2002). Utilizing Cre-Lox technology, our group as well as others have generated mouse models with conditional deletion of the murine homolog of the PTEN gene (Pten) in the brain at different developmental stages (Backman et al., 2001; Groszer et al., 2001; Kwon et al., 2001; Marino et al., 2002; Fraser et al., 2004; Stiles et al., 2004; Yue et al., 2005). By deleting Pten in the embryonic NSCs, we showed PTEN negatively regulates NSC proliferation, survival, and self-renewal, both in vivo and in vitro (Groszer et al., 
2001, 2006). Our recent results demonstrate that Pten null NS/ PCs have enhanced self-renewal capacity, accelerated G0-G1 cell cycle entry, shortened cell cycle, and decreased growth factor dependency (Groszer et al., 2006). Therefore, loss of PTEN is sufficient to increase the pool of self-renewing NSCs and promote their escape from the homeostatic mechanisms of proliferation control while cell fate commitments of the Pten null NS/ PCs are largely undisturbed (Groszer et al., 2001, 2006).

Because PTEN loss can lead to enhanced embryonic NSC selfrenewal, proliferation, and survival, its transient inactivation may be a promising approach for "boosting" the limited adult NSC population, a critical step toward treating certain neurodegenerative diseases. However, such an approach would have to be vigorously tested in vivo to ensure that (1) the PTEN-PI3K pathway plays a similar role in adult NSCs, and (2) perturbation of PTEN-PI3K pathway alone in NSCs is not tumorigenic. To address these issues and further explore the role of PTEN in regulating adult neurogenesis and repair in vivo, we deleted Pten in a subpopulation of adult NS/PCs in the SEZ by crossing Pten conditional knock-out mice (Pten ${ }^{\text {loxp/loxp }}$ ) (Lesche et al., 2002) with a murine GFAP-Cre ${ }^{+}\left(m G F A P-C r e^{+}\right)$transgenic line.

\section{Materials and Methods}

Animals. $m G F A P-C r e^{+}$transgenic mice line 77.6 were generated using a $15 \mathrm{~kb}$ promoter cassette containing the full-length sequence of the murine GFAP gene as described previously for line 73.12 (Garcia et al., 2004) and crossed to Pten ${ }^{\text {loxp/loxp }}$ mice (Lesche et al., 2002) on a 129/BALB/c background. $\mathrm{F}_{1}$ generation compound heterozygous animals were backcrossed with Pten ${ }^{\text {loxp } / l o x p}$ mice to produce $\mathrm{F}_{2}$ generation experimental animals. Animals were genotyped by standard genomic PCR techniques (Lesche et al., 2002). Pten ${ }^{\text {loxp } / l o x p}$; $m G F A P-C r e^{+}$mice were crossed to ROSA26 mice (Soriano, 1999) for reporter analysis. In addition to the SEZ, 77.6 mice exhibited only a scattered mosaic pattern of $\mathrm{Cre} / \beta$-gal expression in subpopulations of $\mathrm{GFAP}^{+}$astrocytes in the adult brain. Animals were housed in a temperature-, humidity-, and light-controlled room (12 h light/dark cycle), and allowed ad libitum access to food and water. All experiments were conducted according to the research guidelines of the University of California at Los Angeles Chancellor's Animal Research Committee. Pten loxp/loxp and Pten ${ }^{\text {loxp } / l o x p} ; m G F A P-C r e^{+}$animals are herein to referred to as control and mutant, respectively.

PCR. The specificity of Pten excision was evaluated by PCR using DNA from tail clip biopsy. For Pten PCR, the loxp ( $650 \mathrm{bp}$ ), wild-type (500 bp), and exon $5(300 \mathrm{bp})$ fragments are amplified simultaneously by using three primers TCCCAGAGTTCATACCAGGA (Pten6637-F), GCAATGGCCAGTACTAGTGA-AC (Pten6925-R), and AATCTGTGCATGAAGGGAAC (Pten7319-R). PCR was performed in $20 \mu \mathrm{l}$ reactions using standard procedures for forty cycles; each cycle consisted of denaturing at $94^{\circ} \mathrm{C}$ for $45 \mathrm{~s}$, annealing at $60^{\circ} \mathrm{C}$ for $30 \mathrm{~s}$, and extension at $72^{\circ} \mathrm{C}$ for $1 \mathrm{~min}$, followed by a single $5 \mathrm{~min}$ extension at $72^{\circ} \mathrm{C}$. The PCR products were analyzed on $2 \%$ agarose gels.

5-Bromo-2'-deoxyuridine labeling. 5-Bromo-2'-deoxyuridine (BrdU; Sigma, B5002) was given as either a single intraperitoneal injection of 200 $\mathrm{mg} / \mathrm{kg}$ followed by perfusion with $4 \%$ paraformaldehyde after $2 \mathrm{~h}$, or as four intraperitoneal injections of $200 \mathrm{mg} / \mathrm{kg}$ every $12 \mathrm{~h}$ followed by perfusion after $14 \mathrm{~d}$. Staining with anti-BrdU antibody (1:1000 BD Biosciences, 51-75512) was performed according to manufacturer's suggestions.

Neurosphere cultures. Neurosphere cultures were prepared as described previously (Groszer et al., 2006). Briefly, 8-week-old SEZs were dissected, minced with a razor blade, dissociated by enzymatic digestion with Accumax followed by light trituration with a fire-polished glass pipette, and passed through a $70 \mu \mathrm{M}$ nylon mesh. For moderate density cultures, cells were resuspended at 10,000 cells/ml (10K) in Neurobasal medium (Invitrogen), supplemented with B-27 ( Invitrogen), Heparin (Sigma), $20 \mathrm{ng} / \mathrm{ml}$ basic fibroblast growth factor (bFGF, Peprotech), and $20 \mathrm{ng} / \mathrm{ml}$ epidermal growth factor (EGF, Invitrogen). For clonal/low density cultures, tertiary neurospheres were dissociated into a single cell suspension as described above and the cells were plated at $1000 \mathrm{cells} / \mathrm{ml}$ $(1 \mathrm{~K})$ in T25 tissue culture flasks. Clonal cultures were passaged every 2 weeks. At passage 1, 4, 8, 16, and 24, cells were also plated into 96 well plates at clonal density and after $10 \mathrm{~d}$ clonal neurospheres were counted and differentiated. All neurospheres in the 96-well clonal plates which measured $>40 \mu \mathrm{M}$ in diameter were counted using the Microcomputer Imaging Device Program (MCID).

Immunocytochemistry of neurospheres. Immunocytochemistry of neurosphere cultures was performed as described previously (Groszer et al., 2001). Briefly, following neurosphere counting, at least 20 randomly chosen clonal neurospheres were transferred from the 96-well plates onto poly-L-lysine (BD Biosciences) and laminin-coated glass coverslips (one sphere per coverslip) for differentiation in Neurobasal medium in the absence of growth factors. After five days, the differentiated neurospheres were fixed in 4\% paraformaldehyde and immunostained with rabbit anti-TUJ1 (1: 1000; Covance, MMS-435P) for neurons.

Image analysis and quantification. BrdU-immunostained $\left(\mathrm{BrdU}^{+}\right)$ nuclei were visualized with a Leica light microscope $(40 \times$ objective) equipped with a charge-coupled device digital camera. For $14 \mathrm{~d}$ postinjection, comparable sections of immunostained profiles contained in the GCL and RMS were counted in $5 \mu \mathrm{m}$ thick serial sections at $100 \mu \mathrm{m}$ intervals. For the $2 \mathrm{~h}$ postinjection period, the numbers of $\mathrm{BrdU}^{+}$nuclei were counted in coronal sections of SEZ and OB. The respective areas of these layers/regions were determined with nuclei were visualized with Ariol SL-50 scanner and analysis system (Applied Imaging/Genetix) software and the quantified values were converted to densities (number of $\mathrm{BrdU}^{+}$profiles per $\left.\mathrm{mm}^{3}\right) ; n=6$. The structure volumes and RMS were measured as described previously (Petreanu and Alvarez-Buylla, 2002; Tsai et al., 2006).

Histology and immunohistochemistry of tissue section. All IHC staining was performed on $5 \mu \mathrm{m}$ sections that were prepared from paraffinembedded blocks and placed on charged glass slides. The slides were deparaffinized with xylene and rehydrated in descending grades $(100 \%-$ $70 \%$ ) of ethanol. The endogenous peroxidase activity was inactivated in $3 \%$ hydrogen peroxide $\left(\mathrm{H}_{2} \mathrm{O}_{2}\right)$. After washing in deionized water, antigen retrieval was performed by incubating the slides in $0.01 \mathrm{M}$ citric acid buffer, $\mathrm{pH} 6.0$, at $95^{\circ} \mathrm{C}$ for $13.5 \mathrm{~min}$. Slides were then allowed to cool for $30 \mathrm{~min}$ in citric acid buffer. After washing in deionized water, the slides were transferred to either PBS, pH 7.4, or TBST for 5 min. For DAB staining, slides were first blocked with $5 \%$ normal goat serum then incubated with primary antibody overnight at $4^{\circ} \mathrm{C}$. Following three $5 \mathrm{~min}$ washes in either PBS or TBST, slides were incubated with biotinylated secondary antibody (1:200, Biogenex) for $30 \mathrm{~min}$ at room temperature. Amplification was performed with a horseradish peroxidase system (Vectastain ABC kit, Vector, PK-6100) using a liquid DAB peroxidase substrate (Biogenex, HK130-5K). Slides were counterstained in Gill's hematoxylin, dehydrated, cleared, and coverslipped. Negative control slides were run without primary antibody. For fluorescence double staining, the section was treated as above and first stained with the first antibody followed by signal amplification with TSA Plus Fluorescence Systems (PerkinElmer, NEL-7448). After biotin blocking, the section was stained with the second antibody and signal was amplified with TSA system with different fluorescence. Primary antibodies used were rabbit anti-PTEN (1:100; Cell Signaling, 9552); rabbit anti-pS6 (1:100; Cell Signaling 2155); rabbit anti-pAKT (1:100; Cell Signaling, 9172); rat antiGFAP (1:1000; ZYMED Laboratories, 18-0063); goat anti-Nestin (1:50; R\&D Systems, AF2736); rabbit anti-Cre (1:3000; Covance PRB-106C); goat anti-doublecortin (1:500; Santa Cruz, sc8066); mouse anti-NeuN (1:1000; Chemicon, MAB377); rabbit anti- $\beta$-galactosidase (1:1000; MP Biochemicals, 55976); rabbit anti-ki-67 (1:100; Vector, VP-RM04). 4',6diamidino-2-phenylindole (DAPI; Invitrogen, D-1306) used as a fluorescent counterstain.

Olfactory habituation test. This task measures the ability of mice to detect a novel odorant and to habituate responding to that odorant over repeated presentations. Previous studies (Trinh and Storm, 2004) demonstrated that a high number of sniffs upon initial exposure of an odorant indicated that the animal detected a novel odorant. Each mouse was housed individually and handled daily for five days before the beginning of any behavioral manipulation. Individual mice were then exposed to an 
odorant for three successive $2 \mathrm{~min}$ trials separated by $1 \mathrm{~min}$ intervals. The first odorant was always sterile water to habituate the animal to the introduction of a novel object (cotton swab) in the home cage. Following this pre-exposure phase, a cotton swab saturated with an odorant was introduced into the home cage for another three successive 2-min trial separated by $1 \mathrm{~min}$ intervals. The total number of contacts that the mouse made with the cotton swab for each of three 2 min exposures as well as the total amount of time spent in contact with the cotton swab was recorded. The odorants used were isoamyl acetate, isomenthone, hexyl alcohol, limonene, and anisole (Sigma). For data collection and analysis, all experiments were recorded using a camcorder. The number of sniffs and the duration of each sniff were analyzed in a blind setting by viewing recordings in real time. To be consistent and unbiased in analysis, a full sheet of plain paper with a 1 in $^{2}$ box was cut out and placed onto the screen with the cotton swab directly in the middle of the box, thus blocking the rest of the screen. Every time the nose of the mouse entered the box, it was scored as a sniff; the duration of each sniff was recorded as the amount of time the nose of the mouse remained in the box. Time intervals were divided into five categories of time as follows: less then 1, 2-5, $6-9,10-12$, and $>12$ s. A total of 14 control and 12 mutant sexually naive male mice at 10-12 months of age were used in behavior experiments.

Chemical ablation of olfactory epithelium. Control and mutant sexually naive 14 - to 16 -week-old male mice $(n=8)$ were housed individually and given intraperitoneal injections of dichlobenil (2.6-dichlobenzonitrile, Sigma, $25 \mu \mathrm{g} / \mathrm{g}$ body weight) in DMSO (dimethyl sulfoxide, $2 \mu \mathrm{l} / \mathrm{g}$ body weight) for $7 \mathrm{~d}$ (Yoon et al., 2005). An additional cohort of control and mutant mice $(n=5)$ were given DMSO (vehicle, $2 \mu \mathrm{l} / \mathrm{g}$ body weight) and evaluated for ability to detect novel odors using the odorant habituation test at 2, 3, and 4 weeks after the last injection.

Stroke model. Stroke was produced in 2- to 5-month-old control and mutant animals. Briefly, stroke was produced using a distal, branch artery occlusion of the middle cerebral artery (Ohab et al., 2006; Tsai et al., 2006). The middle cerebral artery was exposed over the surface of the frontoparietal cortex through a small craniotomy, and a parietal branch coagulated and transected. Both jugular veins in the neck were occluded for $15 \mathrm{~min}$ and then released. This produces a small stroke in he vibrissal (barrel) somatosensory field of the cortex.

Stereology. Stereological quantification was performed using serial sections through the anterior SEZ, OB, and peri-infarct cortex using unbiased counting with the optical fractionator as described previously (Tsai et al., 2006).

Statistical analysis. Unless otherwise noted, all data were subjected to statistical analysis by using two-sample $t$ testing assuming unequal variances (Excel Data Analysis Tool Pak, Microsoft) to determine the differences between the control and mutant groups. A $p$ value of 0.05 or less was considered significant.

\section{Results}

\section{Generation of $m G F A P-C r e^{+}$line for conditionally targeting adult neural stem/progenitor cells}

Previous studies have made a compelling case that the majority of multipotent NSCs responsible for neoneurogenesis in the adult mouse brain express GFAP (Doetsch et al., 1999; Groszer et al., 2001; Imura et al., 2003; Garcia et al., 2004). To further explore the role of PTEN in regulating adult neurogenesis and repair in vivo, we generated a new $\mathrm{mGFAP}-\mathrm{Cr} e^{+}$transgenic line 77.6 using the mGFAP gene cassette (Garcia et al., 2004) (for details, please see Materials and Methods). Immunohistochemistry (IHC) of 77.6 mice crossed to Rosa26-LacZ reporter mice (Soriano, 1999) showed Cre expression in a small subpopulation of SEZ cell in adult brain (Fig. 1a,b) and $\beta$-Gal expression in many more cells corresponding to $\mathrm{Cre}^{+}$cells and their progenies (Fig. 1e). These $\mathrm{Cre}^{+} / \beta-\mathrm{Gal}^{+}$cells represent adult NSCs since their progenies can migrate and differentiate along the RMS (Fig. $1 f$ ) and reach the granule cell layer (GCL) in the OB (Fig. 1h). In addition, we used double-labeling immunohistochemistry to compare expression of Cre with GFAP and Nestin, intermediate filaments whose dynamic regulation by neural progenitors and astrocytes at different stages of development has been well documented (Garcia et al., 2004; Lagace et al. 2007). Three dimensional analysis of SEZ cells using scanning confocal laser microscopy showed that $\mathrm{Cre}^{+}$ cells in the SEZ express GFAP (Fig. 1c) and Nestin (Fig. 1d). Cells that were Cre positive/GFAP negative or Cre positive/Nestin negative were not found (data not shown). Furthermore, neither Cre nor LacZ reporter expression could be detected in embryonic brains (data not shown), suggesting Cre is not expressed during embryonic development, and only postnatally in progenitor cells. In contrast to the previously reported $m G F A P$ lines 7.1 (Bush et al., 1998; Imura et al., 2003) and 73.12 (Garcia et al., 2004), $m G F A P-C r e^{+}$line 77.6-mediated reporter expression in progenitor cells was limited to the SEZ region and no Cre or LacZ reporter expression could be detected in $\mathrm{GFAP}^{+} \mathrm{NSC}$ populations in the hippocampus. Therefore, $m G F A P-C r e^{+}$line 77.6 was chosen for this study because we hypothesized that the limited Cre transgene expression in NSCs of line 77.6 would circumvent increased brain size, altered brain histoarchitecture and premature lethality caused by global Pten deletion from NSCs in previous conditional knock-out models (Groszer et al., 2001; Yue et al., 2005).

\section{Pten deletion in the adult NSC leads to increased self-renewal without tumorigenesis or premature senescence}

To explore PTEN's role in regulating adult NSCs, Pten ${ }^{\text {loxp/loxp }}$ (Lesche et al., 2002) mice were crossed with $m G F A P-C r e^{+}$line 77.6 mice. Pten ${ }^{\text {loxp/loxp }}$; $m$ GFAP-Cre ${ }^{+}$mutants are viable and fertile, yielding Mendelian offspring distributions (data not shown). Importantly, no tumors or aberrant neurological phenotypes were detected in mutant animals up to two years of age.

Previously, we found that deletion of Pten in embryonic NSC resulted in an enhanced ability to self-renew in vitro compared with control spheres (Groszer et al., 2006). To assess the function of PTEN in controlling adult NSC self-renewal and proliferation, we compared neurosphere forming activity of Pten deleted brain (Mutant) with that of their wild-type littermates (Control) in a serial clonal passaging experiment. Similar to Pten deletion in the embryonic neural stem cells, spheres formed from Pten deleted adult brain were generally bigger (supplemental Fig. $1 a$, available at www.jneurosci.org as supplemental material). Importantly, by passage $4>90 \%$ of spheres isolated from the mutant cultures carried Pten bi-allele deletion and were positive for the Cre transgene (supplemental Fig. 1b, available at www.jneurosci. org as supplemental material). At each passage, mGFAP-Cremediated Pten deletion in adult NSCs resulted in increased clonal neurosphere number, a measurement of neural stem cell selfrenewal capacity (Fig. 2a). Serial clonal passaging of cells over 48 weeks (24 passages), at a density at which nearly all spheres are derived from a single cell, resulted in the eventual senescence of wild-type cultures while the mutant cells maintained high rates of self-renewal. This enhanced neurosphere formation was also reflected in the total cell numbers attained at each passage (Fig. 2b). Previous study has suggested that progenitors tend to lose their neurogenic potential and become more glial-restricted over time (Seaberg et al., 2005). Following in vitro differentiation, the clonal neurospheres from mutant mice maintained a significantly enhanced neurogenesis even at late passages, whereas the wild-type cultures produced fewer neurons than their mutant counterpart at every passage and their ability to generate neurons declined substantially with time in culture (Fig. 2c), similar to our previous studies on Pten deleted embryonic NSCs (Groszer et al., 2001). Together, these data indicate that Pten deletion persistently en- 


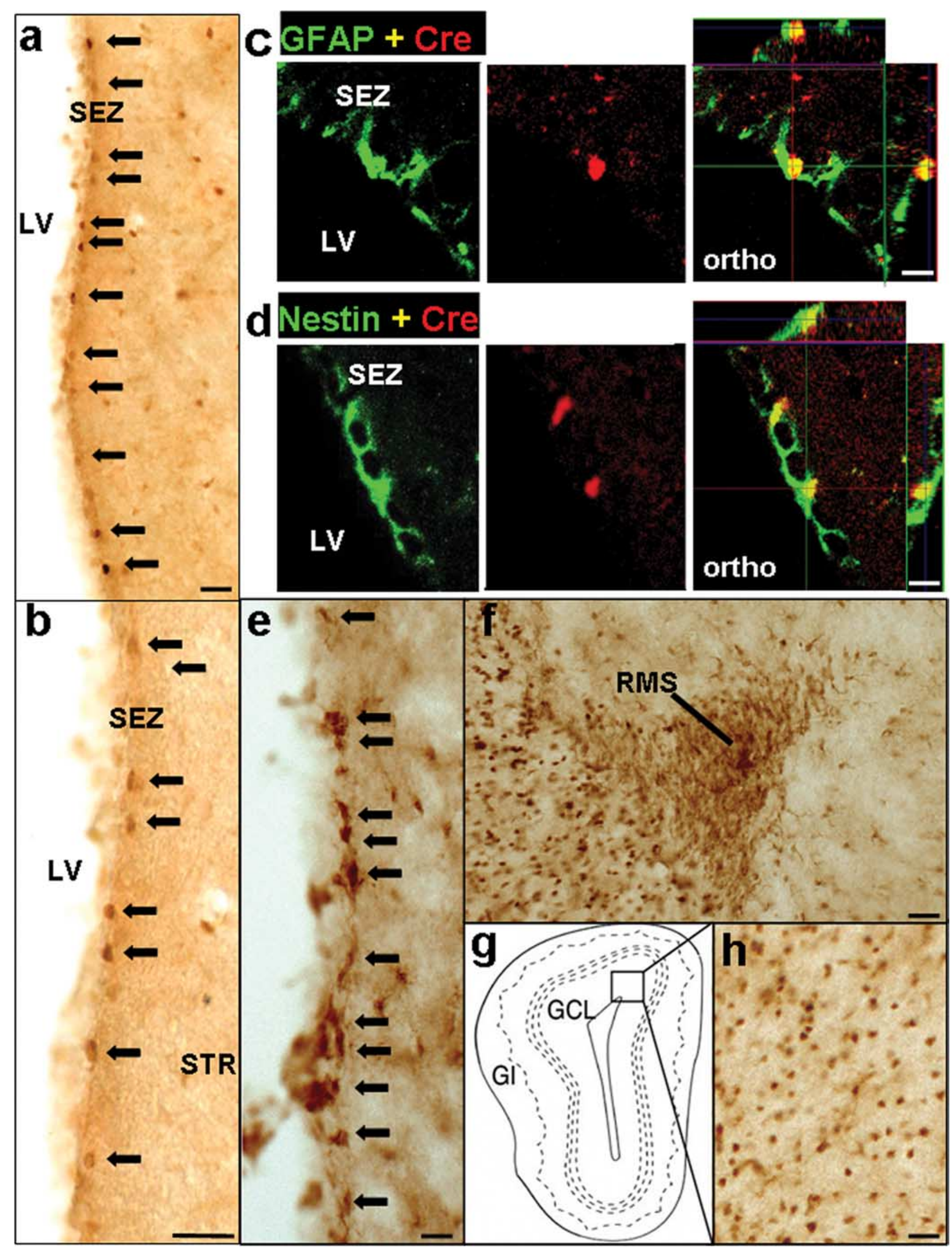

Figure 1. mGFAP-Cre line for conditionally targeting adult neural stem/progenitor cells. $\boldsymbol{a}, \boldsymbol{b}, \boldsymbol{e}, \boldsymbol{f}, \boldsymbol{h}$, Survey images of coronal sections of the SEZ $(\boldsymbol{a}, \boldsymbol{b}, \boldsymbol{e})$, RMS $(\boldsymbol{f})$, and OB $(\boldsymbol{h})$ stained by bright-field immunohistochemistry. A small number of cells in the SEZ express Cre ( $\boldsymbol{a}$, low mag; $\boldsymbol{b}$, high mag). Scale bars, $80 \mu \mathrm{m}$. $\boldsymbol{c}$, $\boldsymbol{d}$, Confocal micrographs of single optical slices through cells in the SEZ that are double stained by immunofluorescence for Cre and GFAP ( $\boldsymbol{c}$ ) or Cre and Nestin (d). Individual channels and orthogonal analysis show that all Cre-expressing (Figure legend continues.) 
hances self-renewal of adult NSC, while maintaining their capacity to produce neurons, without any evidence of stem cell exhaustion.

\section{Pten deletion leads to expansion of neural stem and progenitor cells in the SEZ region}

At the tissue level, Pten deletion led to a robust increase in $\mathrm{GFAP}^{+}$cells (Fig. $3 a$, second right) in the SEZ. Cells with hyperphosphorylation of S6 (P-S6) (Fig. 3a, third right) and AKT (P-AKT; supplemental Fig. $2 a$, available at www.jneurosci.org as supplemental material), surrogate markers for PTEN loss and PI3K activation that have been implicated in neuron survival and cell cycle control (Datta et al., 1999), could be easily visualized in the same region. GFAP expression and numbers of $\mathrm{GFAP}^{+}$cells did not appear different from controls in neighboring structures and other parts of forebrain except the SEZ region (data not shown), further supporting SEZ-specific Pten deletion. Importantly, these $\mathrm{P}-\mathrm{S}^{+}$cells also express GFAP (Fig. 3a) and/or Doublecortin (DCX), a marker for immature and migrating neuroblast progenitors (supplemental Fig. $2 b$, available at www. jneurosci.org as supplemental material), suggesting that PTEN loss or PI3K-AKT activation leads to the expansion of adult NSC and progenitors in SEZ region.

Consistent with NSC expansion, the volume of the mutant SEZ is significantly increased when compared with controls (Fig. $3 b)(0.021 \pm 0.0011$ vs $0.032 \pm 0.008$ $\mathrm{mm}^{3} \pm$ SEM; $\left.p<0.01\right)$, which was accompanied by a greater number of Ki-67 ${ }^{+}$(Fig. 3 c) $(6832.12 \pm 231.8$ vs $8376.98 \pm 122.8$ cells \pm SEM; $p<0.01$ ) and DCX ${ }^{+}$neuroblasts (Feng and Walsh, 2001). Figure $3 d$ shows a statistically significant increase in DCX volume in Pten ${ }^{\text {loxp/loxp; }} m$ GFAP-Cre ${ }^{+}$SEZ (Fig. 3d) (0.019 \pm 0.0012 vs $\left.0.062 \pm 0.0064 \mathrm{~mm}^{3} \pm \mathrm{SEM} ; p<0.01\right)$. These results indicated that Pten null NSCs can readily proliferate and differentiate into $\mathrm{DCX}^{+}$neuroblasts, the precursors for adult neurogenesis.

SEZ-born Pten null progenitors and their progenies follow the endogenous migration pathway

SEZ-born progenitors are known to migrate to the $\mathrm{OB}$ via the well-defined RMS. Because PTEN has been implicated in controlling cell chemotaxis (Funamoto et al., 2002; Iijima and Dev-

(Figure legend continued.) cells in the SEZ also express GFAP (c) and Nestin (d). Orthogonal images (ortho) show three-dimensional analysis of individual cells at specific sites marked by intersecting $x, y$, and $z$ axes. Scale bars, $20 \mu \mathrm{m}$. Many cells express the reporter protein $\beta$-gal (e) in the neurogenic proliferative regions of the SEZ. Migrating neuroblasts in the RMS $(\boldsymbol{f})$ and granule neurons in the $\mathrm{OB}(\boldsymbol{h})$ also express $\beta$-gal. Box in $g$ indicates the region shown in $\boldsymbol{h}$. Arrows in $\boldsymbol{a}, \boldsymbol{b}$, and $\boldsymbol{e}$ indicate representative Cre or $\beta$-gal-positive cells in SEZ. SEZ, Subependmyal zone; LV, left ventricle; STR, striatum; RMS, rostral migratory stream; OB, olfactory bulb; $\mathrm{GCL}$, granule cell layer; $\mathrm{Gl}$, glomeruli. b Total cell number at each passage
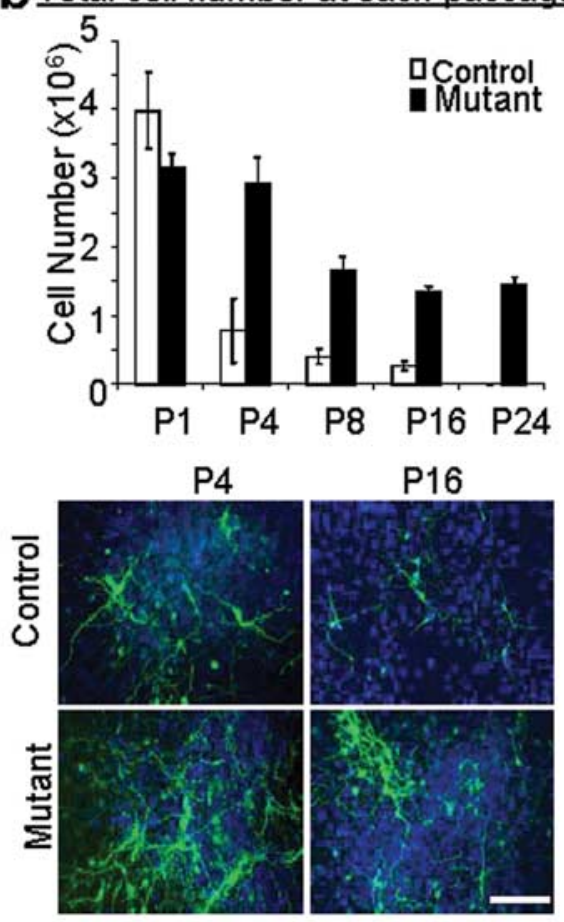

Figure 2. Pten deletion in clonal neurosphere cultures enhances stem cell self-renewal and neurogenesis over long-term serial clonal passages compared with the gradual senescence and decreased neurogenesis in wild-type cultures. $\boldsymbol{a}$, Neurosphere cultures generated from the adult SVZ of Pten knock-out (Mutant) and wild-type (Control) mice were cultured at clonal density (1000 , passaged, and reseeded at clonal density every 2 weeks. Clonal neurosphere numbers, representative of the number of indicating the clonal neurospheres from mutant mice maintained their robust neurogenesis even at late clonal passages while the ability to generate neurons was dramatically attenuated in control cultures over time. Scale bar, $60 \mu \mathrm{m} . n=4$.

reotes, 2002) as well as migration (Tamura et al., 1998; Liliental et al., 2000; Raftopoulou et al., 2004; Yue et al., 2005), we determined whether the progenies of SEZ-born Pten null progenitors could respond to normal environmental cues and migrate into and along the RMS. To mark the SEZ-born progenitors and their differentiated progenies, we pulse labeled control and mutant mice with BrdU and quantified the number of $\mathrm{BrdU}^{+}$ cells in the RMS after $5 \mathrm{~d}$ of chase. As shown in Figure $4 a$, a significant increase in the number of $\mathrm{BrdU}^{+}$cells was found in the mutant RMS (Fig. 4a) (22998 \pm 968 vs $33386 \pm 786$ cells per $\mathrm{mm}^{3} \pm$ SEM; $\left.p<0.05\right)$. Furthermore, the $\mathrm{BrdU}^{+}$cells were also positive for P-S6 staining (Fig. 4a), indicating that SEZ-born Pten null progenitors exhibited enhanced cell proliferation but could follow the endogenous migration pathway into the RMS.

We then tested whether the migrating Pten null progenitors within the RMS express similar markers as controls. Neuroblasts in mutant RMS are Pten ${ }^{-}$(supplemental Fig. 3, available at www. jneurosci.org as supplemental material) and DCX ${ }^{+}$(Fig. 4b) with

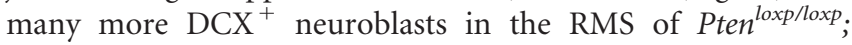
$m$ GFAP-Cre ${ }^{+}$mice (Fig. $\left.4 b\right)(2642 \pm 126$ vs $3894 \pm 60$ cells per $\mathrm{mm}^{2} \pm$ SEM; $\left.p<0.05\right)$.

During migration, neuroblasts are restricted to the RMS with few cells diverging from the path (Doetsch and AlvarezBuylla, 1996). Although it seemed that a greater number of 
Control
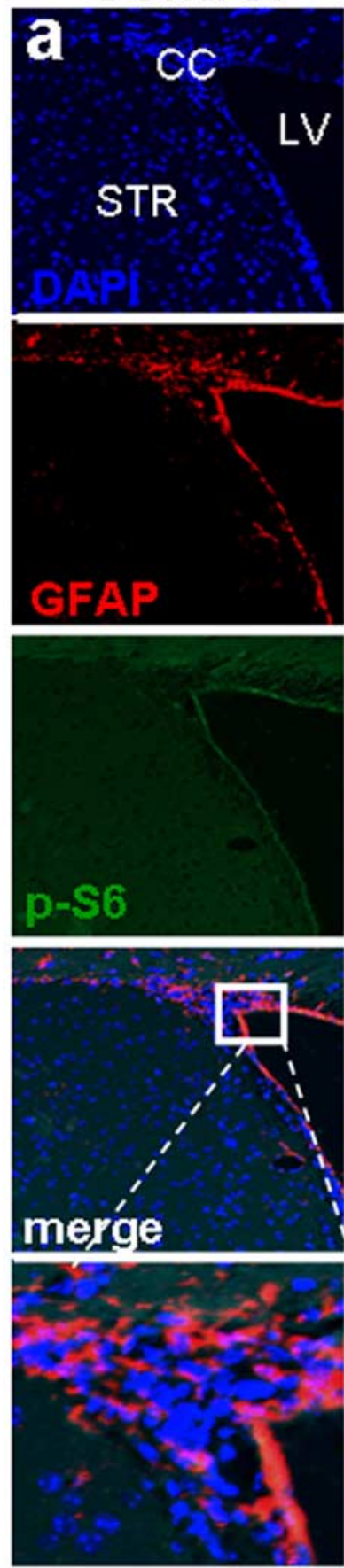

Mutant
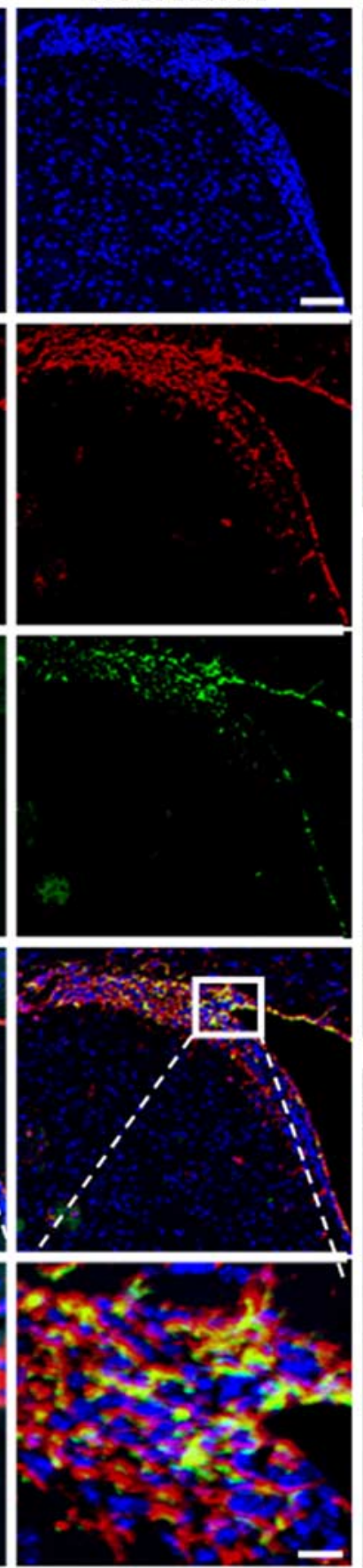

Control
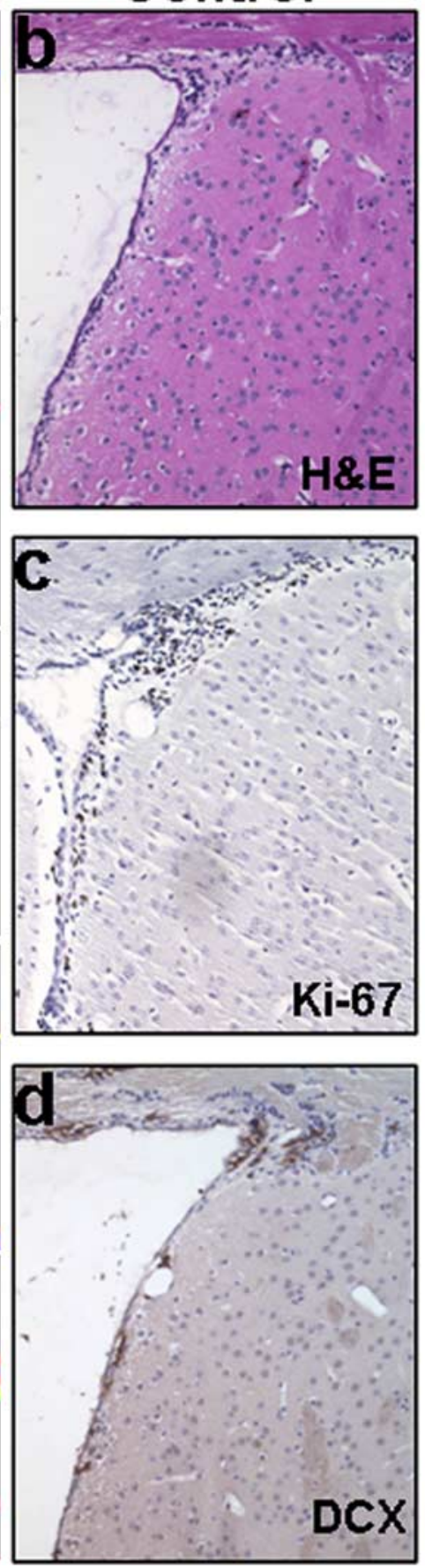

Mutant
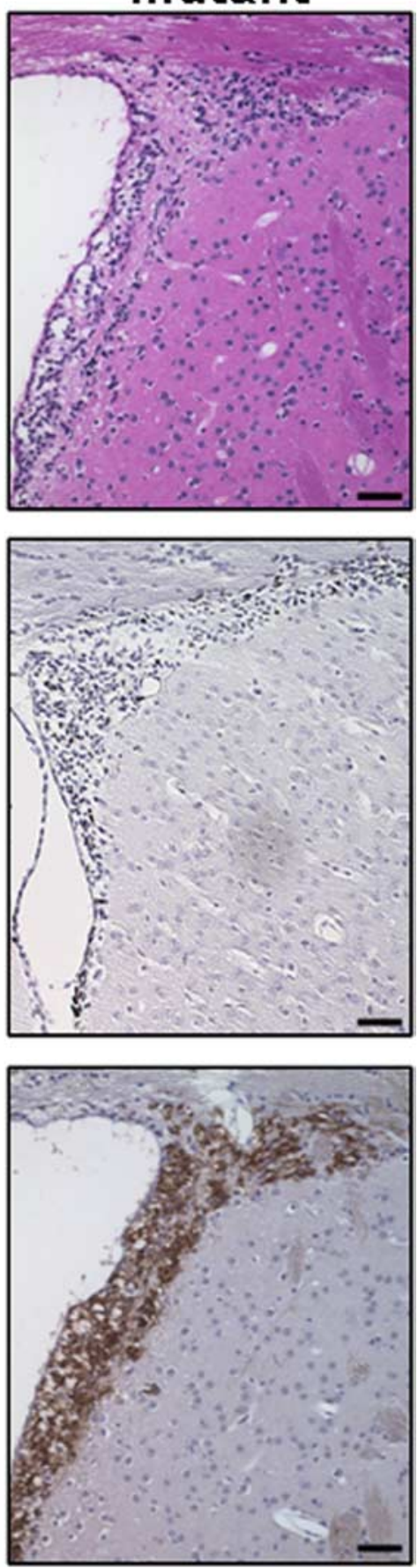

Figure 3. mGFAP-Cre-mediated Pten deletion leads to expansion of adult neural stem cells and their progenies in vivo. Survey images of coronal sections of control and mutant SEZ. $\boldsymbol{a}$, Compared with littermate controls, mutant mice showed increased GFAP and P-S6-positive (labeled cells which co-localized in the SEZ. DAPI counter stain is used to visualize nuclei. Scale bars: top, $150 \mu$ m; bottom, $25 \mu \mathrm{m} . \boldsymbol{b}-\boldsymbol{d}$, Images of H\&E (b), Ki-67 (c), and DCX (d) expression demonstrate increased proliferation in mutant SEZ compared with control regions. Scale bar, $60 \mu \mathrm{m}$. $n=5$. SEZ, Subependymal zone; LV, lateral ventricle; CC, corpus callosum; STR, striatum; H\&E, hematoxylin and eosin; DCX, doublecortin.

cells diverged from the RMS in the Pten ${ }^{\operatorname{loxp} / l o x p}$; $m$ GFAP-Cre mice, the ratio of diverging DCX ${ }^{+}$cells to the total number of cells in the mutant RMS was not significantly different from that of controls $(1.28 \pm 0.004$ vs $1.36 \pm 0.009 \%$ of total \pm SEM; $p>0.05)$. These results suggest that Pten null SEZ-born neuroblasts are able to recognize environmental cues and migrate along the endogenous pathway.
Deletion of Pten in adult SEZ leads to increased OB mass Although OB granule cell neurons (GC) are continuously generated throughout adulthood, $\mathrm{OB}$ volume remains constant during adulthood (Pomeroy et al., 1990). This homeostatic stage is achieved largely via a balance between SEZ neoneurogenesis and cell death in the GCL of OB (Najbauer and Leon, 1995; Fiske and Brunjes, 2001; Petreanu and Alvarez-Buylla, 2002). Measure- 

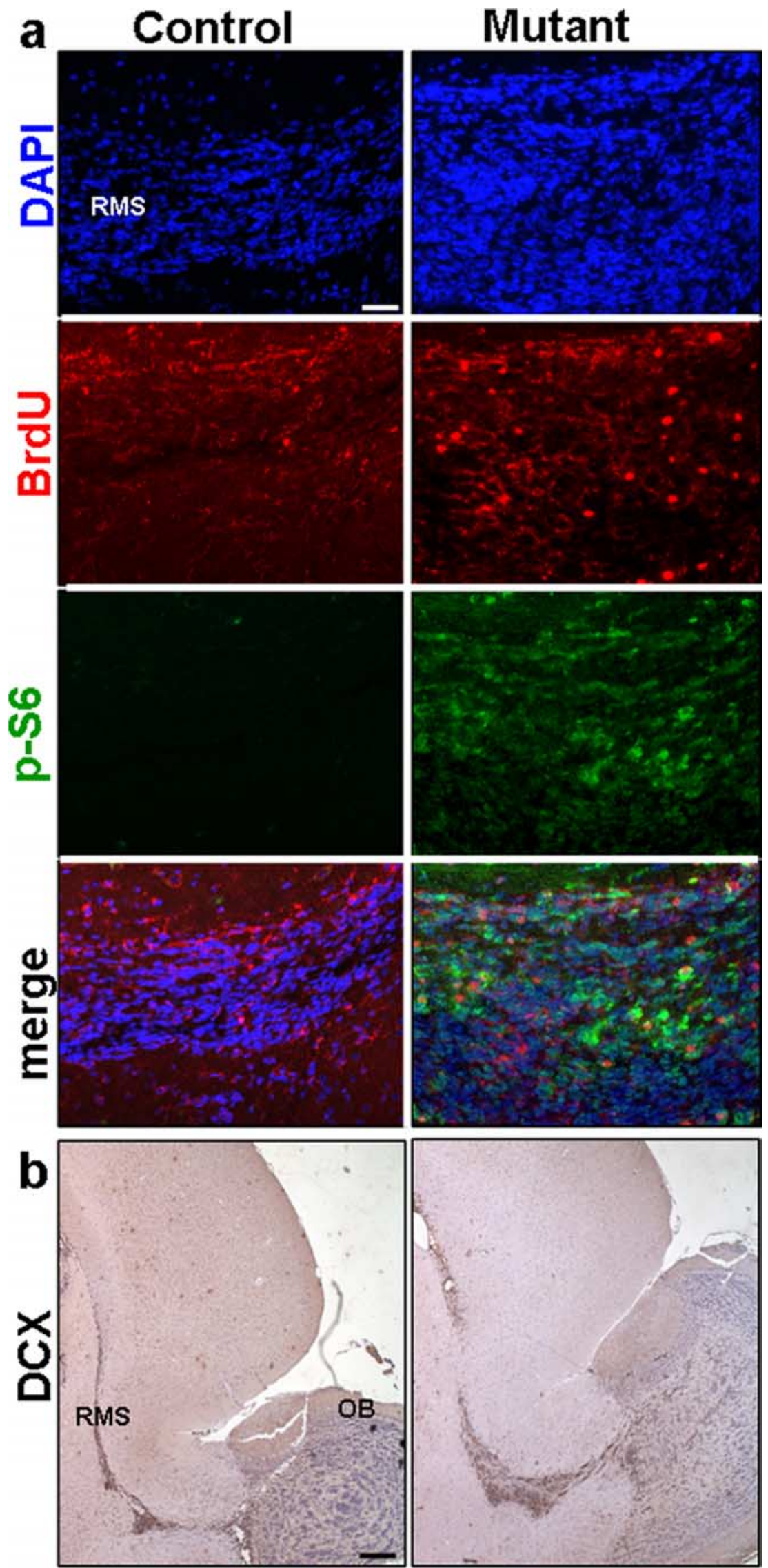

Figure 4. Pten deletion leads to enhanced migration of SEZ-born progenitors in RMS. $\boldsymbol{a}$, Representative images of RMS stained for BrdU, P-S6, and their colocalization revealed an increase in Pten null SEZ-born progenitors migrating in RMS when compared with control and shows the BrdU ${ }^{+}$population in mutant RMS is Pten null. Scale bar, $100 \mu \mathrm{m}$. $\boldsymbol{b}$, Survey images of sagittal ments taken from mutants and their littermate controls demonstrated continuous increases in size (Fig. $5 a$, upper panel) and weight of mutant $\mathrm{OB}$, starting at 2.5 months of age (Fig. $5 a$, lower panel). This increased size and mass of mutant $\mathrm{OB}$ is consistent with previous reports that there is a surge of progenitors migrating to the $\mathrm{OB}$ at 3-4 months of age (Petreanu and Alvarez-Buylla, 2002). Histological analysis of mutant $\mathrm{OB}$ (Fig. 5b) and other brain regions (supplemental Fig. 4, available at www.jneurosci.org as supplemental material) revealed normal histoarchitecture.

Because SEZ-born progenitors migrate and integrate into the GCL of the $\mathrm{OB}$, we hypothesized that an increase in GCL volume may contribute to the increased $\mathrm{OB}$ mass. Compared with control, Pten ${ }^{\text {loxp/loxp }}$; $m G F A P-C r e^{+}$GCL volume increased twofold at 3.5 months (Fig. $5 c$, columns on the left) $\left(2.92 \pm 0.071\right.$ vs $5.60 \pm 0.25 \mathrm{~mm}^{3} \pm$ SEM; $p<0.05)$ while no statistically significant differences were observed in the external plexiform layer (EPL) (Fig. 5c, columns on the right) $(1.19 \pm 0.054$ vs $\left.1.10 \pm 0.043 \mathrm{~mm}^{3} \pm \mathrm{SEM} ; p>0.05\right)$, a region not influenced by SEZ-mediated neurogenesis. To further test whether increased GCL volume is due to SEZ-born granule cells incorporated into the $\mathrm{OB}$, mice were injected with BrdU and killed at $2 \mathrm{~h}$ or $14 \mathrm{~d}$ after the last injection. These time points were chosen to ensure that there were no ectopic proliferating cells in the mutant $\mathrm{OB}$ ( $2 \mathrm{~h}$ chase) and to allow sufficient time for BrdU-labeled neuroblasts to migrate, differentiate, and incorporate into the outer layers of the $\mathrm{OB}(14 \mathrm{~d}$ chase). BrdU ${ }^{+}$cells could not be detected in either control or mutant $\mathrm{OB}$ after $2 \mathrm{~h}$ of chase (supplemental Fig. 5, available at www.jneurosci.org as supplemental material). However, after $14 \mathrm{~d}$ chase there was an approximate twofold increase in the number of BrdU ${ }^{+}$cells in the GCL of 3.5month-old Pten ${ }^{\text {loxp/loxp }}$; $m$ GFAP-Cre ${ }^{+}$ mice when compared with wild-type controls (Fig. $5 d)(2.92 \pm 0.07$ vs $5.60 \pm 0.25$ cells \pm SEM; $p<0.001)$. These results indicate that the increase in GCL volume was not due to ectopic cell proliferation within the OB but from an increase in the number of cells that migrated from the SEZ to the GCL via the RMS. We also observed a sig-

\footnotetext{
sections of control and mutant RMS stained with $D C X$ demonstrate an increase in the number of migrating neuroblasts in mutant RMS compared with control. DAPI counter stain is used to visualize nuclei. Scale bar, 400 $\mu \mathrm{m} . n=6$. DCX, Doublecortin; RMS, rostral migratory stream; $\mathrm{OB}$, olfactory bulb.
} 

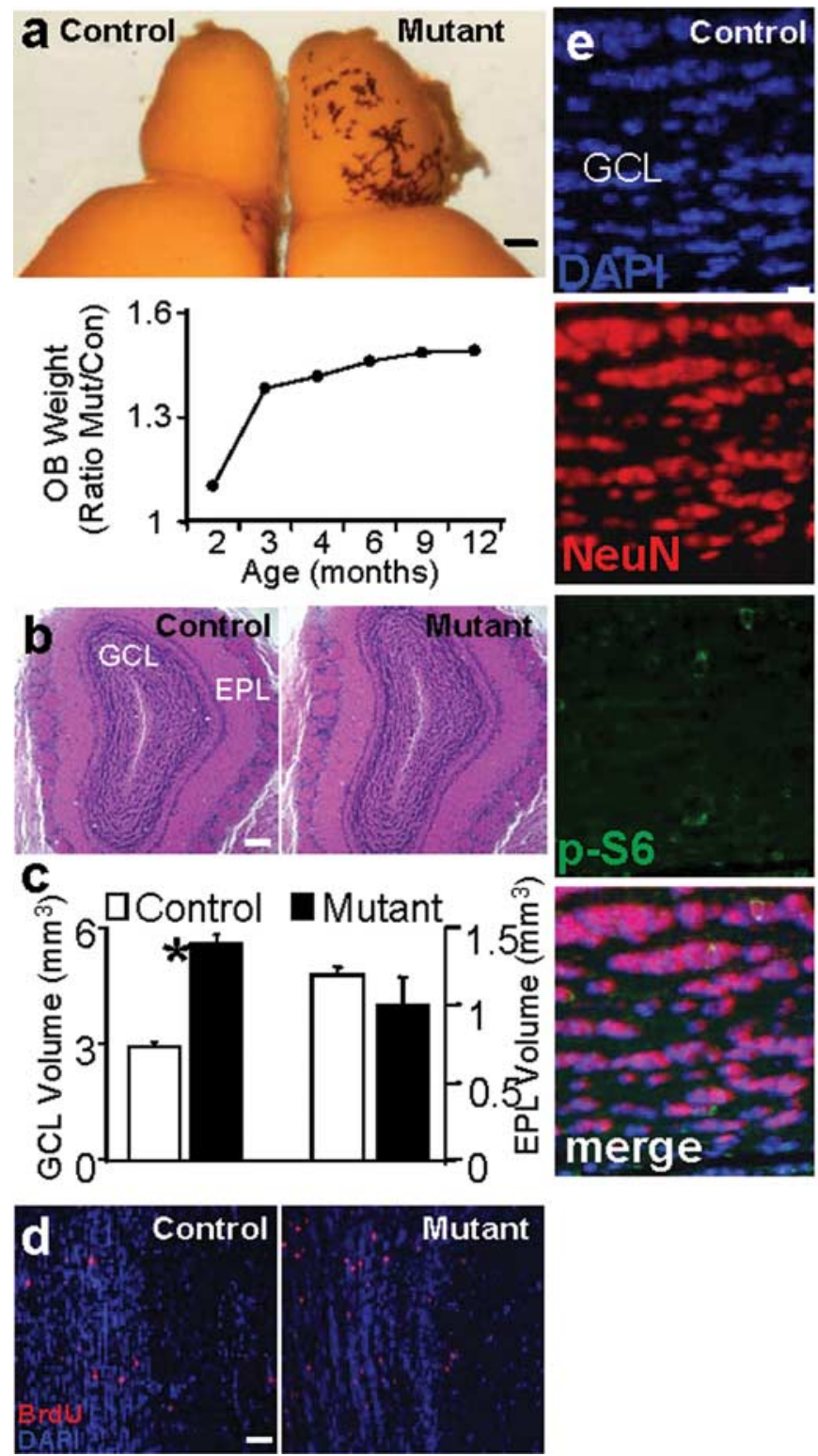

Figure 5. Increased $O B$ mass and enhanced proliferation and migration of SEZ-born progenitors to the $G C L$ of $O B$ in mutant mice. $a$, Enlarged OB of mutant mice. Photo shows a brain hemisphere from age-matched control and mutant mice. Scale bar, 1 $\mathrm{mm}$. Panel below depicts the progressive increase in the ratio of mutant/control OB weight. $n=40 . \boldsymbol{b}$, Histological analysis of $O B$ section from control and mutant mice reveals normal histoarchitecture. Scale bar, $500 \mu \mathrm{m}$. C, GCL volume is significantly increased in mutant mice $\left({ }^{*} p<0.05\right)$ whereas no significant change is observed in EPL $(p>0.05)$. Data are means $\pm S E M ; n=10 . \boldsymbol{d}$, SEZ-born neuroblast migration was analyzed by BrdU pulse-labeling. Mice were injected with $200 \mathrm{mg} / \mathrm{kg}$ BrdU peritoneally, and distribution of BrdU-labeled cells was determined 2 weeks after injection. An increased number of BrdU-labeled cells within mutant GCL indicated Pten mutant mice had a significant increase in cell number at 2 weeks post injection. Scale bar, $100 \mu \mathrm{m} . n=$ 5. $\boldsymbol{e}$, Representative GCL images show enhanced immunoreactivity for NeuN and increased NeuN/P-S6 double positive cells in mutant when compared with a matched control region. DAPI is used as counterstain to visualize nuclei. Scale bar, $10 \mu \mathrm{m}$. 0B, Olfactory bulb; GCL, granule cell layer; EPL, external plexiform layer.

nificant decrease in the number of TUNEL $^{+}$cells in the mutant GCL $2.51 \pm 0.22$ (control) vs $1.83 \pm 0.16$ (mutant) cells \pm SEM; $p<0.05$ ), indicating that $\mathrm{OB}$ enlargement in the mutant mice is a net result of increased cell proliferation and decreased cell death. Furthermore, Pten null NSC-derived granule neurons in the GCL were positive for both P-S6 and NeuN, a neuron-specific marker (Fig. 5e). Together, these results indicate that Pten deleted NSCs and their progenies can follow endogenous cues along the normal RMS and reach the OB. Within the OB, they can differentiate and integrate into the GCL.
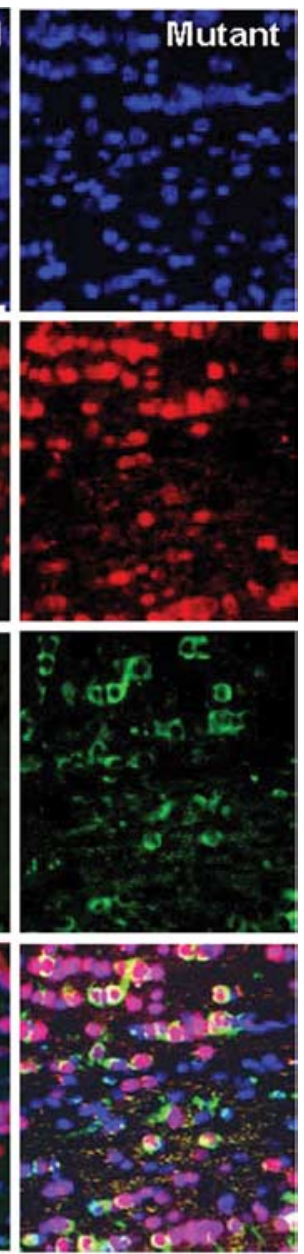

Pten $^{\text {loxp/loxp} ; m G F A P-C r e ~}{ }^{+}$mice exhibit enhanced habituation to novel odors The life-long neurogenesis along SEZRMS-OB suggests that adult-born neurons play critical roles in olfactory functions (Petreanu and Alvarez-Buylla, 2002; Winner et al., 2002): adult-born neurons extend new processes and form new synapses with each other or with existing GC (Cecchi et al., 2001; Petreanu and AlvarezBuylla, 2002), and the rates of neurogenesis are known to be positively correlated with performance on memory (Nilsson et al., 1999; Shors et al., 2001; Rochefort et al., 2002) and olfactory discrimination tasks (Gheusi et al., 2000; Enwere et al., 2004). To test whether SEZ-derived Pten null GCs are functional, we performed an olfactory behavioral test. This Odorant Habituation Task behavioral assay measures the ability of mice to detect a novel odorant and to habituate in responding to that odorant over repeated presentations (Trinh and Storm, 2004). We found that olfactory discrimination was intact in Pten ${ }^{\text {loxp/loxp }}$ $m G F A P-C r e^{+}$mice since the first exposure to an odorant resulted in an increase in the number of sniffs from the previous trial, proving that the mice were able to detect a novel odor (Fig. 6a). Furthermore, mutant mice habituate faster to a novel odorant when compared with controls, as demonstrated by a decrease in the number of sniffs during the second and third exposures of both isoamyl acetate and isomenthone (Fig. $6 a$, right panels). A similar pattern was observed with two additional odorants regardless of order of presentation (data not shown). In addition, when the duration of the sniffs was measured, Pten ${ }^{\text {loxp } / l o x p} ; m$ GFAP-Cre ${ }^{+}$mice exhibited a decrease in the time spent within each odorant group compared with controls (supplemental Fig. 6, available at www. jneurosci.org as supplemental material). A decrease in the time spent investigating an odorant after repeating exposure further implies that Pten ${ }^{\text {loxp/loxp }}$; $m$ GFAP-Cre ${ }^{+}$ mice have an increased ability to recall, recognize, or habituate to the odorant when compared with control.

This enhanced odorant habituation suggests that 1) Pten deletion in adult NSC causes enhanced proliferation and self-renewal without interfering with the normal properties and destiny of their differentiated progenies, and 2) Pten null granule neurons are able to integrate into the olfactory circuitry and contribute to odor discrimination. We therefore hypothesized that perturbation of endogenous PTEN function may be beneficial for neuronal repair and postinjury recovery. To test this hypothesis, mice were treated with dichlobenil, a chemical shown to selectively destroy the olfactory sensory epithelium (Mombaerts et al., 1996; Yoon et al., 2005) in adult mice. In agreement with published reports, we observed a 
severe destruction of the main olfactory epithelium (MOE) neuronal layer in animals treated with dichlobenil when compared with controls (supplemental Fig. 7, available at www.jneurosci. org as supplemental material). Post dichlobenil treatment, all mice were evaluated weekly for their ability to detect novel odors (Odorant Habituation Test as described above). Consistent with previous report (Yoon et al., 2005), all drug treated mice, regardless of genotype, lost their ability to detect odorants 2 weeks after treatment (Fig. $6 b$, top panel). However, Pten ${ }^{\text {loxp } / \text { loxp }} ; m G F A P$ $\mathrm{Cre}^{+}$mice showed an improvement in odorant detection 4 weeks post treatment (Fig. $6 b$, middle panel). MOE examination after 4 weeks of dichlobenil treatment showed comparable regeneration of the epithelial layer in both control and mutant mice with no significant difference in Pten (supplemental Fig. $8 b$, available at www.jneurosci.org as supplemental material) or P-S6 (supplemental Fig. $8 c$, available at www.jneurosci.org as supplemental material) staining, indicating improved behavioral test performance in the mutant animals is not due to enhanced regeneration or Pten deletion in mutant MOE. By 6 weeks post treatment, the Pten ${ }^{\text {loxp/loxp }}$; $\mathrm{GFAP}-\mathrm{Cre}^{+}$mice had almost recovered to pretreatment stage (Fig. $6 b$, bottom panel). These results suggest Pten null cells in the $\mathrm{OB}$ can establish normal connections with peripheral olfactory epithelium and enhanced NSC self-renewal and proliferation in Pten deleted SEZ may help OB recovery from acute damage.

\section{Pten deletion enhances poststroke neuroblast migration}

Stroke is a common cause of neuronal damage. Seven to ten days after the initial insult, SEZ-born neuroblasts proliferate and migrate to the site of injury, contributing to poststroke neurogenesis and recovery (Arvidsson et al., 2002; Parent, 2002; Jin et al., 2003; Tsai et al., 2006). We tested whether Pten deletion in SEZ NSCs could enhance neuroblast proliferation and migration after ischemic injury. For this, we introduced a limited stroke in the sensorimotor cortex of the brain, which closely mimics the human condition and quantified the location and number of immature neurons with the protein marker doublecortin (DCX) (Carmichael, 2005; Ohab et al., 2006). As reported in normal adult mice (Ohab et al., 2006; Tsai et al., 2006), there were no DCX ${ }^{+}$ cells in the cortex of either control or Pten ${ }^{\text {loxp } / \text { loxp }} ; m G F A P-\mathrm{Cre}^{+}$ mice before stroke (data not shown), suggesting that Pten null NSCs in the SEZ do not migrate to the cortex without additional stimulation (supplemental Fig. 9, available at www.jneurosci.org as supplemental material). Conditional Pten deletion also had no effect on infarct size $\left(1.57 \pm 0.38\right.$ vs $1.48 \pm 0.34 \mathrm{~mm}^{3} \pm$ SEM; $p>$ $0.05)$.

One week after stroke, $\mathrm{DCX}^{+}$cells were found in subcortical white matter and peri-infarct cortex of both groups (Fig. 7a, left panels). However, Pten $^{\text {loxp } / \text { loxp }} ; m$ GFAP-Cre ${ }^{+}$mice showed a large and statistically significant increase of $\mathrm{DCX}^{+}$neuroblasts in the peri-infarct cortex at day 7 when compared with controls (Fig. $7 a$, right panels) ( $>4500$ more immature neurons per animal in mutant vs control; $p<0.001)$, suggesting that Pten null NSCs and their progenies can readily respond to ischemic injury and migrate to the damaged site. Staining of P-S6 marker further supports the idea that it is Pten null neuroblasts which contribute to the increased $\mathrm{DCX}^{+}$population in the peri-infarct site (Fig. $7 b$ ). These results indicate that PTEN is a potent negative regulator of $\mathrm{NSC} /$ progenitor proliferation and neurogenesis in response to injury.

Previous studies have shown that despite the migration of large numbers of newly born immature neurons to peri-infarct cortex in the first week after stroke, only a small percentage sur-

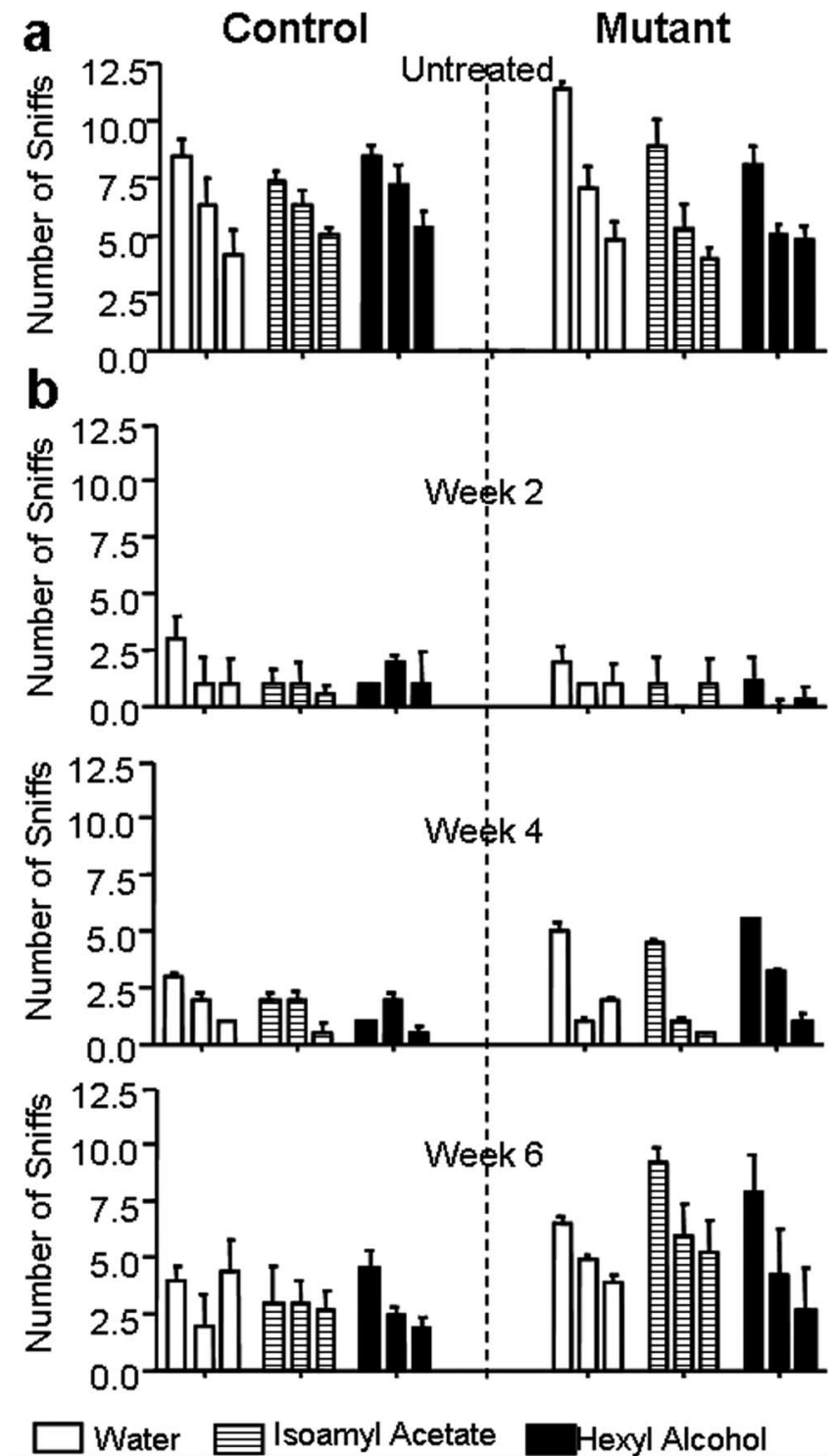

Figure 6. Enhanced olfactory habituation and recovery after epithelium injury in $P^{\text {Pten }}{ }^{\text {Ioxp /loxp }}$; mGFAP-Cre ${ }^{+}$mice. $\boldsymbol{a}, \boldsymbol{b}$, Control and mutant mice were subjected to the olfactory habituation test. Pretraining of wild-type control mice to a cotton swab soaked in water habituated mice to the presence of the swab in their cage. This was manifested as a decline in the number of sniffs with subsequent exposures to the swab. During odorant testing, the cotton swab was laced with $50 \mu \mathrm{m}$ isoamyl acetate or $50 \mu \mathrm{m}$ hexyl alcohol and introduced on three successive trials. The fact that the control mice sniffed the isoamyl acetate- and hexyl alcohollaced cotton swabs more times than during the third exposure to the water swab indicated that the animal was able to smell these odorants. $\boldsymbol{a}$, Compared with control, mutant mice sniffed the swabs less frequently in the second and third exposures (all three conditions) signifying they habituated to the novel odorant faster than the control. $n=14$ (control) and 12 (mutant). $\boldsymbol{b}$, Both control and mutant mice lost their ability to detect odorants at 2 weeks post treatment, whereas the ability of mutant mice to detect odorants began recovering at 4 weeks post treatment, and their ability to detect odorants was restored to pre-treatment levels by week 6 . Data are means $\pm \mathrm{SEM} ; n=8$.

vive long term (Arvidsson et al., 2002; Ohab et al., 2006). To determine if PTEN plays a role in the long-term survival and differentiation of immature neurons in regions of damage after stroke, we labeled newly born cells in the first week after stroke with BrdU, and co-labeled these cells 90 d later with double staining for the mature neuronal marker NeuN. There was no difference in stereological counts of BrdU/NeuN cells between Pten ${ }^{\text {loxp/loxp }} ;$ GGFAP-Cre ${ }^{+}$mice and littermate controls $90 \mathrm{~d}$ after 


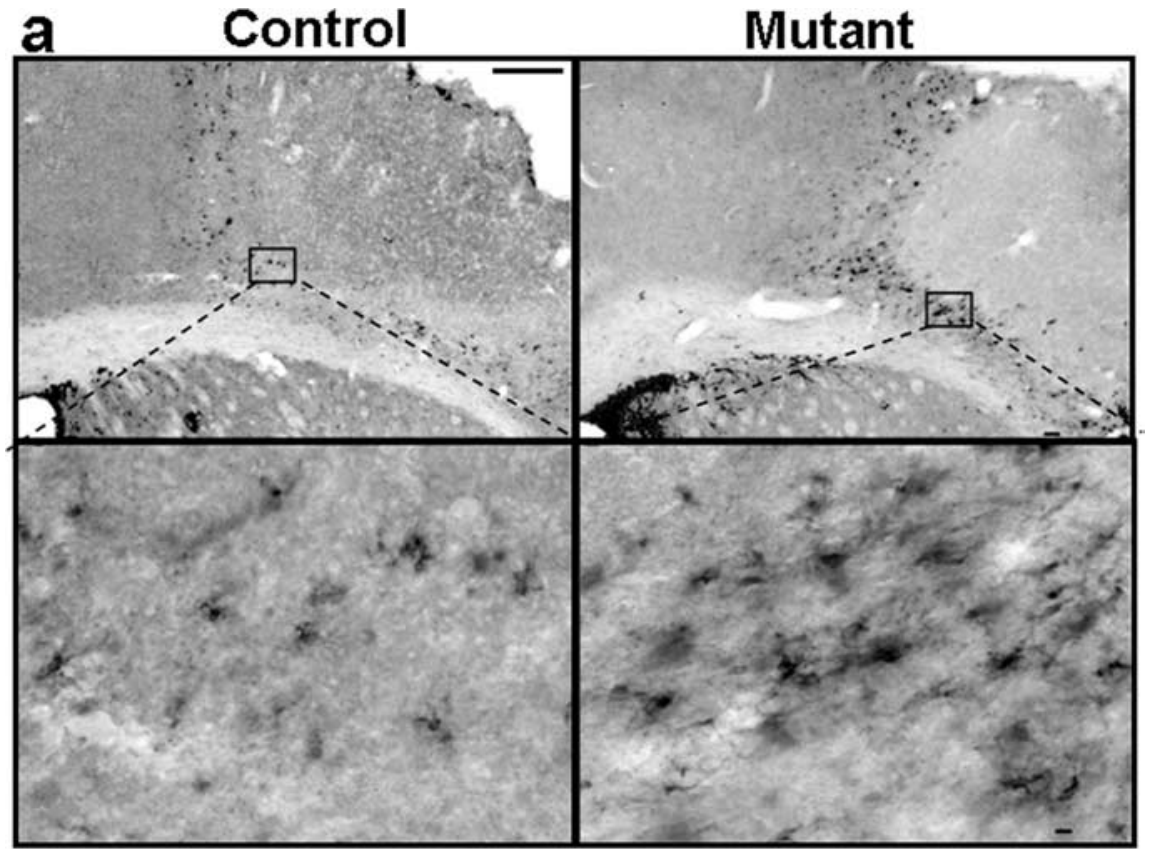

b Contralateral
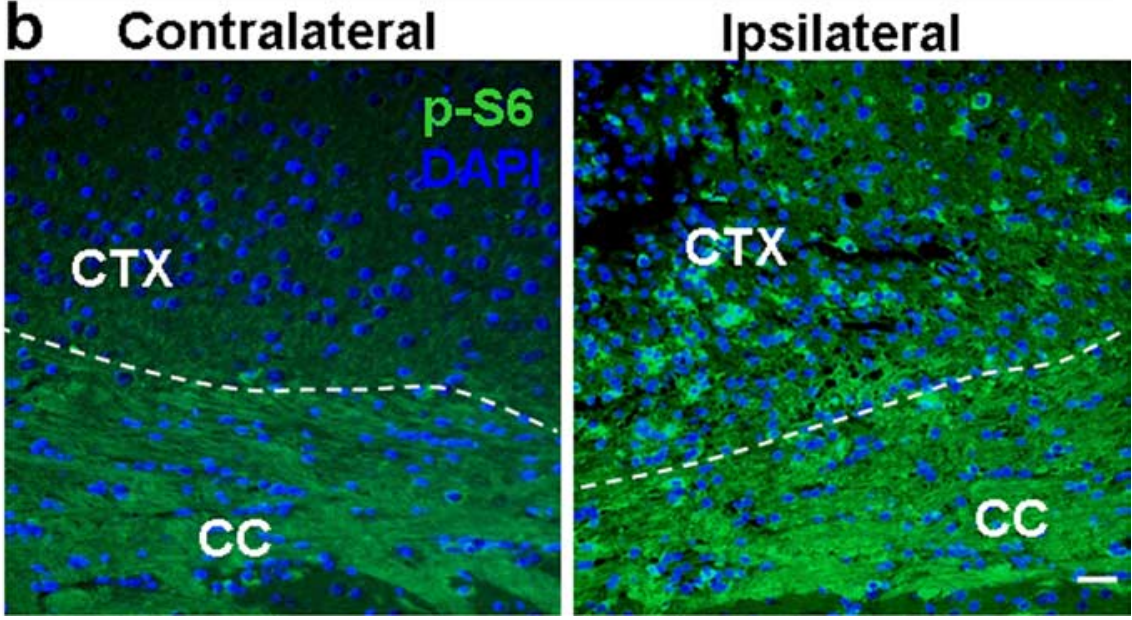

Figure 7. Pten deletion enhances post-stroke neuroblast migration. $a, \mathrm{DCX}$ labeling in peri-infarct cortex and SEZ. DCX ${ }^{+}$cells in control and mutant $7 \mathrm{~d}$ after stroke. Right panel shows stereological quantification of $D C X^{+}$cells in peri-infarct cortex. Scale bars: top, $100 \mu \mathrm{m}$; bottom, $25 \mu \mathrm{m} . n=6 . b$, Representative images of P-S6 staining from both hemispheres of mutant mouse. Left panel shows hemisphere containing peri-infarct cortex which has increased staining for $\mathrm{p}$ - $\mathbf{6} 6$ in peri-infarct cortex when compared with uninjured cortex in the same animal (right panel). DAPI is used as counterstain to visualize nuclei. Scale bar, 50 $\mu \mathrm{m}$. CTX, Cortex; CC, corpus callosum.

stroke $(315 \pm 123$ vs $303 \pm 199$ cells per animal in mutant and control \pm SEM, respectively; $p>0.05$ ). This data indicate that although PTEN plays a prominent role in the control the initial proliferation and migration of immature neurons in poststroke neurogenesis, it does not play an autonomous role in the survival of these cells in the long term.

\section{Discussion}

Neurological disorders are the leading source of disability. Currently there are no treatments that promote repair and recovery in the brain from any major neurological disorder, including stroke, degenerative disease, and trauma. NSCs are cells that can give rise to the major components of the brain and spinal cord, thus attractive resources for repairing neurological disorders (Lindvall and Kokaia, 2006). The major challenges of NSCmediated neuronal repair are 1) to understand the key pathways involved in controlling NSC self-renewal, proliferation, survival and differentiation, 2) to develop methodologies for manipulating these pathways toward therapeutic use, and 3) to test the potential benefit of NSCs and their progenies in human disease-relevant model systems before being used on human patients.

In this study we demonstrated that deletion of Pten in adult NSCs is not tumorigenic but promotes NSC expansion. Progeny from Pten null NSCs follow the endogenous migratory cues, differentiate, and integrate into the existing circuitry. Under conditions of acute damage, such as olfactory epithelium ablation, animals with Pten NSC deletion exhibited faster recovery. These data suggest that conditional manipulation of the PTEN/PI3K pathway in NSCs may be beneficial for NSC expansion, proliferation, and survival, in turn, promoting recovery and the integration of newly born neurons to existing or damaged neuronal networks associated with constitutive neurogenesis.

Stem cell self-renewal is known to be regulated by different signaling pathways, but the effect of a specific pathway may depend on the developmental stage or lineage of a stem cell population. For example, deletion of p21 in adult neural stem cells results in a transient increase in neurospheres formation with a subsequent decline in stem cell numbers; a phenomenon known as stem cell "exhaustion" (Kippin et al., 2005). Although, in a similar manner, PTEN loss leads to the "exhaustion" of adult hematopoietic stem cells (Yilmaz et al., 2006; Zhang et al., 2006; and our unpublished observation), conditional deletion of Pten in both embryonic and adult NSC promotes a sustained selfrenewal and stem/progenitor expansion (Groszer et al., 2006; Groszer et al., 2001; and this study). Significantly, we observed that the mutant cultures maintain an enhanced self-renewal, proliferation/survival rate, over extremely long-term expansion times under clonal conditions, suggesting that the role of PTEN in regulating stem cell activity may be modulated by factors specific to the neural stem cell lineage. Therefore, further study of these lineage- or developmental stage-specific mediators of self-renewal pathways will be increasingly critical for our understanding of the underlying mechanisms of stem cell selfrenewal and therapeutic manipulations.

In the current study, we demonstrated enhanced and prolonged neurogenic capacity in clonal cultures of Pten-deleted neural stem/progenitor cells compared with wild-type controls. In our first report of Pten mutant embryonic progenitors, we did not expand cultures for prolonged periods of time, and therefore did not observe this phenomenon. However, more recently, in an experiment using serial passaging of embryonic progenitors, we also observed similar results to those reported here. Although Pten deletion promotes neuronal survival, we do not think that 
this effect, in and of itself, accounts for the observed enhancement in neurogenesis, as the observed enhancement in neuronal production appears similar between Pten deleted and wild-type neurospheres at early passages as well. It is possible that Pten deletion in some way promotes a neuronal cell fate to some extent but this is not necessarily at the expense of glial differentiation. Instead, we view the enhanced maintenance of neurogenesis as being largely due to the fact that Pten deletion is allowing for the maintenance of a multipotent stem cell-like pool that retains neuronal competence, whereas multiply passaged wild-type cultures do not maintain stem cells production, and become enriched for glial restricted precursors (Bhattacharyya and Svendsen, 2003; Jain et al., 2003; Seaberg et al., 2005).

Our previous studies and those by others demonstrated that Pten deletion in the embryonic brain leads to abnormal histoarchitecture with severe layering defects (Backman et al., 2001; Groszer et al., 2001; Marino et al., 2002; Yue et al., 2005). However, as Pten deletion happens in nearly $100 \%$ of the neural stem/ progenitor cells, it is unclear whether the abnormal phenotypes observed are caused by intrinsic migratory defects of Pten-null neurons, extrinsic microenvironmental cues provided by Pten null radial glia, or perhaps both (Groszer et al., 2001). In this study, we demonstrated that in the presence of wild-type environmental cues, Pten null adult NSCs and their progenies can follow the endogenous migration pathway, undergo differentiation, and reach their normal target. This result is consistent with a previous study on Pten heterozygous mice showing that Pten $^{+/-}$cells migrated to the outer layers of the OB more rapidly and incorporated at the same sites as Pten ${ }^{+/+}$cells (Li et al., 2002). Therefore, the extrinsic microenvironment cues plays a more predominant role in controlling the migratory behavior of SEZ-derived Pten null NSCs and their progenies.

Nearly $90 \%$ of the GCs in the OB are SEZ-derived and incorporated postnatally, and their survival depends on incoming activities (Rosselli-Austin and Williams, 1990; Brunjes, 1994). GCs are also known to extensively shape mitral cell response to odors (Yokoi et al., 1995), and there is evidence that the OB circuitry maximizes differences in odor representations (Friedrich and Laurent, 2001; Dulac, 2005). Animals carrying a mutation in the cyclic nucleotide gated channel are not able to transduce the signal from the olfactory receptors in the olfactory neurons (Baker et al., 1999) and have smaller GCL volume and OB mass (Petreanu and Alvarez-Buylla, 2002). The lack of electrical activity in the $\mathrm{OB}$ of these mice dramatically reduced the survival of newly generated neurons of the GCL, suggesting that peripheral olfactory epithelium plays a critical role in the survival of GCL neurons in the OB (Petreanu and Alvarez-Buylla, 2002). Our results showed that PTEN loss in SEZ NSCs leads to an increase in GCL volume and $\mathrm{OB}$ size as well as an improvement in olfactory function, suggesting that the Pten null SEZ-derived GCL neurons are able to integrate into the existing circuitry, receive electrical input from olfactory epithelium and are thus functional. Because olfactory ablation/repair is a multifactor-dependent process, we cannot rule out that mechanisms other than Pten null granular cells in the $\mathrm{OB}$ also contribute to the faster recovery observed in our study. Since Pten conditional deletion in adult NSCs also enhances the recovery of olfactory function after ablation of olfactory epithelium, our data suggest an important role for SEZderived neurons in reestablishment of the connection between $\mathrm{OB}$ and olfactory epithelium during acute damage via a currently unknown mechanism.

SEZ-born progenitors are known to play a role in postischemic injury recovery (Ohab et al., 2006). In a stroke-injury model, Pten conditional knock-out animals showed a robust increase in cell proliferation and $\mathrm{DCX}^{+}$neuroblast migration from the SEZ over long distances to the peri-infarct cortex, suggesting Pten null neuroblasts are responsive to chemotactic stimulation and can migrate to the injury site. Although the SEZ DCX volume did not increase in Pten conditional knock-out mice poststroke when compared with non-stroke animals (supplemental Fig. 10, available at www.jneurosci.org as supplemental material), the significantly enhanced proliferation and migration of Pten null neuroblasts to the peri-infarct cortex suggested that Pten null neuroblasts are primed for the signals that induce poststroke neurogenesis. Pten deletion might have been expected to promote neuroblast survival as it potentiates the action of the PI3K/Akt pathway, a common downstream signaling pathway for many of the neural stem cell survival and differentiation growth factors (Greenberg and Jin, 2006). Interestingly, Pten conditional deletion in these neuroblasts is not sufficient to promote their longterm differentiation/survival and functional integration once they have migrated into peri-infarct cortex. Thus, in addition to soluble growth factor signaling, the cellular environment of the peri-infarct cortex may exert an important degree of control over cell survival in newly born neurons after stroke.

Stem cell-based therapies, including the promotion of endogenous neurogenesis or transplantation of stem/progenitor cells, are limited in large part by the death of the progenitor pool (Goldman, 2005). In poststroke neurogenesis, despite a robust generation of newly born neurons, ninety percent of them eventually die (Ohab et al., 2006). After stem/progenitor transplantation, a similar result is seen in which most transplanted cells die or fail to differentiate. The differential roles of PTEN defined in the present study highlight the key differences between constitutive/ normal and injury-induced neurogenesis. PTEN inactivation alone is sufficient to promote a significant increase in neurogenesis, neuronal survival and improved function in the olfactory bulb but insufficient to promote long-term survival after stroke. Although both poststroke and normal neurogenesis involve growth factor signaling within glial and vascular niches (Nilsson et al., 1999; Teramoto et al., 2003; Ohab et al., 2006; Hagg, 2007; Puche and Baker, 2007) poststroke neurogenesis requires additional, likely, cellular signals that are independent of the common PI3K-AKT-mediated growth factor signaling pathway. In designing successful stem cell based therapies it will be important to determine both the molecular and cellular constituents that support survival and differentiation of stem cell progenies.

\section{References}

Arvidsson A, Collin T, Kirik D, Kokaia Z, Lindvall O (2002) Neuronal replacement from endogenous precursors in the adult brain after stroke. Nat Med 8:963-970.

Backman SA, Stambolic V, Suzuki A, Haight J, Elia A, Pretorius J, Tsao MS, Shannon P, Bolon B, Ivy GO, Mak TW (2001) Deletion of Pten in mouse brain causes seizures, ataxia and defects in soma size resembling Lhermitte-Duclos disease. Nat Genet 29:396-403.

Baker H, Cummings DM, Munger SD, Margolis JW, Franzen L, Reed RR, Margolis FL (1999) Targeted deletion of a cyclic nucleotide-gated channel subunit ( $\mathrm{OCNC1}$ ): biochemical and morphological consequences in adult mice. J Neurosci 19:9313-9321.

Bhattacharyya A, Svendsen CN (2003) Human neural stem cells: a new tool for studying cortical development in Down's syndrome. Genes Brain Behav 2:179-186.

Brunjes PC (1994) Unilateral naris closure and olfactory system development. Brain Res Brain Res Rev 19:146-160.

Bush TG, Savidge TC, Freeman TC, Cox HJ, Campbell EA, Mucke L, Johnson MH, Sofroniew MV (1998) Fulminant jejuno-ileitis following ablation of enteric glia in adult transgenic mice. Cell 93:189-201. 
Carmichael ST (2005) Rodent models of focal stroke: size, mechanism, and purpose. NeuroRx 2:396-409.

Cecchi GA, Petreanu LT, Alvarez-Buylla A, Magnasco MO (2001) Unsupervised learning and adaptation in a model of adult neurogenesis. J Comput Neurosci 11:175-182.

Curtis MA, Kam M, Nannmark U, Anderson MF, Axell MZ, Wikkelso C, Holtås S, van Roon-Mom WM, Björk-Eriksson T, Nordborg C, Frisén J, Dragunow M, Faull RL, Eriksson PS (2007) Human neuroblasts migrate to the olfactory bulb via a lateral ventricular extension. Science 315:1243-1249.

Datta SR, Brunet A, Greenberg ME (1999) Cellular survival: a play in three Akts. Genes Dev 13:2905-2927.

Doetsch F (2003) The glial identity of neural stem cells. Nat Neurosci 6:1127-1134.

Doetsch F, Alvarez-Buylla A (1996) Network of tangential pathways for neuronal migration in adult mammalian brain. Proc Natl Acad Sci U S A 93:14895-14900.

Doetsch F, Caillé I, Lim DA, García-Verdugo JM, Alvarez-Buylla A (1999) Subventricular zone astrocytes are neural stem cells in the adult mammalian brain. Cell 97:703-716.

Dulac C (2005) Molecular architecture of pheromone sensing in mammals. Novartis Found Symp 268:100-107; discussion 107- 110:167-170.

Emsley JG, Mitchell BD, Kempermann G, Macklis JD (2005) Adult neurogenesis and repair of the adult CNS with neural progenitors, precursors, and stem cells. Prog Neurobiol 75:321-341.

Enwere E, Shingo T, Gregg C, Fujikawa H, Ohta S, Weiss S (2004) Aging results in reduced epidermal growth factor receptor signaling, diminished olfactory neurogenesis, and deficits in fine olfactory discrimination. J Neurosci 24:8354-8365.

Feng Y, Walsh CA (2001) Protein-protein interactions, cytoskeletal regulation and neuronal migration. Nat Rev Neurosci 2:408-416.

Fiske BK, Brunjes PC (2001) Cell death in the developing and sensorydeprived rat olfactory bulb. J Comp Neurol 431:311-319.

Fraser MM, Zhu X, Kwon CH, Uhlmann EJ, Gutmann DH, Baker SJ (2004) Pten loss causes hypertrophy and increased proliferation of astrocytes in vivo. Cancer Res 64:7773-7779.

Friedrich RW, Laurent G (2001) Dynamic optimization of odor representations by slow temporal patterning of mitral cell activity. Science 291:889-894.

Funamoto S, Meili R, Lee S, Parry L, Firtel RA (2002) Spatial and temporal regulation of 3-phosphoinositides by PI 3-kinase and PTEN mediates chemotaxis. Cell 109:611-623.

Garcia AD, Doan NB, Imura T, Bush TG, Sofroniew MV (2004) GFAPexpressing progenitors are the principal source of constitutive neurogenesis in adult mouse forebrain. Nat Neurosci 7:1233-1241.

Gheusi G, Cremer H, McLean H, Chazal G, Vincent JD, Lledo PM (2000) Importance of newly generated neurons in the adult olfactory bulb for odor discrimination. Proc Natl Acad Sci U S A 97:1823-1828.

Goldman S (2005) Stem and progenitor cell-based therapy of the human central nervous system. Nat Biotechnol 23:862-871.

Goldman SA (1998) Adult neurogenesis: from canaries to the clinic. J Neurobiol 36:267-286.

Greenberg DA, Jin K (2006) Growth factors and stroke. NeuroRx 3:458-465.

Groszer M, Erickson R, Scripture-Adams DD, Lesche R, Trumpp A, Zack JA, Kornblum HI, Liu X, Wu H (2001) Negative regulation of neural stem/ progenitor cell proliferation by the Pten tumor suppressor gene in vivo. Science 294:2186-2189.

Groszer M, Erickson R, Scripture-Adams DD, Dougherty JD, Le Belle J, Zack JA, Geschwind DH, Liu X, Kornblum HI, Wu H (2006) PTEN negatively regulates neural stem cell self-renewal by modulating G0-G1 cell cycle entry. Proc Natl Acad Sci U S A 103:111-116.

Hack MA, Saghatelyan A, de Chevigny A, Pfeifer A, Ashery-Padan R, Lledo PM, Götz M (2005) Neuronal fate determinants of adult olfactory bulb neurogenesis. Nat Neurosci 8:865-872.

Hagg T (2007) Endogenous regulators of adult CNS neurogenesis. Curr Pharm Des 13:1829-1840.

Iijima M, Devreotes P (2002) Tumor suppressor PTEN mediates sensing of chemoattractant gradients. Cell 109:599-610.

Imura T, Kornblum HI, Sofroniew MV (2003) The predominant neural stem cell isolated from postnatal and adult forebrain but not early embryonic forebrain expresses GFAP. J Neurosci 23:2824-2832.
Jain M, Armstrong RJ, Elneil S, Rosser AE, Barker RA (2003) Migration and differentiation of transplanted human neural precursor cells. Neuroreport 14:1257-1262.

Jin K, Sun Y, Xie L, Peel A, Mao XO, Batteur S, Greenberg DA (2003) Directed migration of neuronal precursors into the ischemic cerebral cortex and striatum. Mol Cell Neurosci 24:171-189.

Kippin TE, Martens DJ, van der Kooy D (2005) p21 loss compromises the relative quiescence of forebrain stem cell proliferation leading to exhaustion of their proliferation capacity. Genes Dev 19:756-767.

Kwon CH, Zhu X, Zhang J, Knoop LL, Tharp R, Smeyne RJ, Eberhart CG, Burger PC, Baker SJ (2001) Pten regulates neuronal soma size: a mouse model of Lhermitte-Duclos disease. Nat Genet 29:404-411.

Lee JO, Yang H, Georgescu MM, Di Cristofano A, Maehama T, Shi Y, Dixon JE, Pandolfi P, Pavletich NP (1999) Crystal structure of the PTEN tumor suppressor: implications for its phosphoinositide phosphatase activity and membrane association. Cell 99:323-334.

Lesche R, Groszer M, Gao J, Wang Y, Messing A, Sun H, Liu X, Wu H (2002) Cre/loxP-mediated inactivation of the murine Pten tumor suppressor gene. Genesis 32:148-149.

Li J, Simpson L, Takahashi M, Miliaresis C, Myers MP, Tonks N, Parsons R (1998) The PTEN/MMAC1 tumor suppressor induces cell death that is rescued by the AKT/protein kinase $\mathrm{B}$ oncogene. Cancer Res 58:5667-5672.

Li L, Liu F, Salmonsen RA, Turner TK, Litofsky NS, Di Cristofano A, Pandolfi PP, Jones SN, Recht LD, Ross AH (2002) PTEN in neural precursor cells: regulation of migration, apoptosis, and proliferation. Mol Cell Neurosci 20:21-29.

Liaw D, Marsh DJ, Li J, Dahia PL, Wang SI, Zheng Z, Bose S, Call KM, Tsou HC, Peacocke M, Eng C, Parsons R (1997) Germline mutations of the PTEN gene in Cowden disease, an inherited breast and thyroid cancer syndrome. Nat Genet 16:64-67.

Liliental J, Moon SY, Lesche R, Mamillapalli R, Li D, Zheng Y, Sun H, Wu H (2000) Genetic deletion of the Pten tumor suppressor gene promotes cell motility by activation of Rac1 and Cdc42 GTPases. Curr Biol 10:401-404.

Lindvall O, Kokaia Z (2006) Stem cells for the treatment of neurological disorders. Nature 441:1094-1096.

Lledo PM, Alonso M, Grubb MS (2006) Adult neurogenesis and functional plasticity in neuronal circuits. Nat Rev Neurosci 7:179-193.

Lois C, García-Verdugo JM, Alvarez-Buylla A (1996) Chain migration of neuronal precursors. Science 271:978-981.

Luskin MB (1993) Restricted proliferation and migration of postnatally generated neurons derived from the forebrain subventricular zone. Neuron 11:173-189.

Maehama T, Taylor GS, Dixon JE (2001) PTEN and myotubularin: novel phosphoinositide phosphatases. Annu Rev Biochem 70:247-279.

Marino S, Krimpenfort P, Leung C, van der Korput HA, Trapman J, Camenisch I, Berns A, Brandner S (2002) PTEN is essential for cell migration but not for fate determination and tumourigenesis in the cerebellum. Development 129:3513-3522.

Mombaerts P, Wang F, Dulac C, Chao SK, Nemes A, Mendelsohn M, Edmondson J, Axel R (1996) Visualizing an olfactory sensory map. Cell 87:675-686.

Najbauer J, Leon M (1995) Olfactory experience modulated apoptosis in the developing olfactory bulb. Brain Res 674:245-251.

Nelen MR, van Staveren WC, Peeters EA, Hassel MB, Gorlin RJ, Hamm H, Lindboe CF, Fryns JP, Sijmons RH, Woods DG, Mariman EC, Padberg GW, Kremer H (1997) Germline mutations in the PTEN/MMAC1 gene in patients with Cowden disease. Hum Mol Genet 6:1383-1387.

Nilsson M, Perfilieva E, Johansson U, Orwar O, Eriksson PS (1999) Enriched environment increases neurogenesis in the adult rat dentate gyrus and improves spatial memory. J Neurobiol 39:569-578.

Ohab JJ, Fleming S, Blesch A, Carmichael ST (2006) A neurovascular niche for neurogenesis after stroke. J Neurosci 26:13007-13016.

Parent JM (2002) The role of seizure-induced neurogenesis in epileptogenesis and brain repair. Epilepsy Res 50:179-189.

Peterson DA (2002) Stem cells in brain plasticity and repair. Curr Opin Pharmacol 2:34-42.

Petreanu L, Alvarez-Buylla A (2002) Maturation and death of adult-born olfactory bulb granule neurons: role of olfaction. J Neurosci 22:6106-6113.

Pomeroy SL, LaMantia AS, Purves D (1990) Postnatal construction of neural circuitry in the mouse olfactory bulb. J Neurosci 10:1952-1966. 
Puche AC, Baker H (2007) Olfactory cell derivation and migration. J Mol Histol 38:513-515.

Raftopoulou M, Etienne-Manneville S, Self A, Nicholls S, Hall A (2004) Regulation of cell migration by the $\mathrm{C} 2$ domain of the tumor suppressor PTEN. Science 303:1179-1181.

Rochefort C, Gheusi G, Vincent JD, Lledo PM (2002) Enriched odor exposure increases the number of newborn neurons in the adult olfactory bulb and improves odor memory. J Neurosci 22:2679-2689.

Rosselli-Austin L, Williams J (1990) Enriched neonatal odor exposure leads to increased numbers of olfactory bulb mitral and granule cells. Brain Res Dev Brain Res 51:135-137.

Seaberg RM, Smukler SR, van der Kooy D (2005) Intrinsic differences distinguish transiently neurogenic progenitors from neural stem cells in the early postnatal brain. Dev Biol 278:71-85.

Shors TJ, Miesegaes G, Beylin A, Zhao M, Rydel T, Gould E (2001) Neurogenesis in the adult is involved in the formation of trace memories. Nature 410:372-376.

Soriano P (1999) Generalized lacZ expression with the ROSA26 Cre reporter strain. Nat Genet 21:70-71.

Stiles B, Groszer M, Wang S, Jiao J, Wu H (2004) PTENless means more. Dev Biol 273:175-184.

Tamura M, Gu J, Matsumoto K, Aota S, Parsons R, Yamada KM (1998) Inhibition of cell migration, spreading, and focal adhesions by tumor suppressor PTEN. Science 280:1614-1617.

Teramoto T, Qiu J, Plumier JC, Moskowitz MA (2003) EGF amplifies the replacement of parvalbumin-expressing striatal interneurons after ischemia. J Clin Invest 111:1125-1132.

Trinh K, Storm DR (2004) Detection of odorants through the main olfactory epithelium and vomeronasal organ of mice. Nutr Rev 62:S189-192 discussion S224-141.

Tsai PT, Ohab JJ, Kertesz N, Groszer M, Matter C, Gao J, Liu X, Wu H, Carmichael ST (2006) A critical role of erythropoietin receptor in neurogenesis and post-stroke recovery. J Neurosci 26:1269-1274.

Vivanco I, Sawyers CL (2002) The phosphatidylinositol 3-Kinase AKT pathway in human cancer. Nat Rev Cancer 2:489-501.

Winner B, Cooper-Kuhn CM, Aigner R, Winkler J, Kuhn HG (2002) Longterm survival and cell death of newly generated neurons in the adult rat olfactory bulb. Eur J Neurosci 16:1681-1689.

Yamashita T, Ninomiya M, Hernández Acosta P, García-Verdugo JM, Sunabori T, Sakaguchi M, Adachi K, Kojima T, Hirota Y, Kawase T, Araki N, Abe K, Okano H, Sawamoto K (2006) Subventricular zone-derived neuroblasts migrate and differentiate into mature neurons in the post-stroke adult striatum. J Neurosci 26:6627-6636.

Yokoi M, Mori K, Nakanishi S (1995) Refinement of odor molecule tuning by dendrodendritic synaptic inhibition in the olfactory bulb. Proc Natl Acad Sci U S A 92:3371-3375.

Yoon H, Enquist LW, Dulac C (2005) Olfactory inputs to hypothalamic neurons controlling reproduction and fertility. Cell 123:669-682.

Yue Q, Groszer M, Gil JS, Berk AJ, Messing A, Wu H, Liu X (2005) PTEN deletion in Bergmann glia leads to premature differentiation and affects laminar organization. Development 132:3281-3291. 